\title{
Gnotobiotic evaluation of Dalbergia sissoo genotypes for resistance against Fusarium solani via dual culture set up
}

\author{
Monika Chauhan', Ajay Thakur ${ }^{1 *}$, Y Yashaswi Singh ${ }^{1}$ D, M. Maqbool Rather ${ }^{2}$ and Nirmal S. K. Harsh ${ }^{3}$
}

\begin{abstract}
Background: Dalbergia sissoo (shisham), an important multipurpose tree native to the Indian subcontinent and also planted in other countries, has been afflicted with large scale mortality in all age groups due to wilt disease, causing huge economic losses. Fusarium solani f. sp. dalbergiae ( $F s d$ ) has been identified as one of the causal organisms for wilt disease in D. sissoo. One of the approaches of disease resistance studies involves co-cultivation of trees and pathogens under controlled conditions to screen resistant tree genotypes. A gnotobiotic condition, where the pathogen is known, enables accurate screening of disease-resistant genotypes. In the present study, ten genotypes of D. sissoo were cloned in vitro and evaluated against two strains of Fsd in a dual culture setup under gnotobiotic conditions with an objective to identify resistant genotypes of D. sissoo against Fsd.

Results: Callus and plantlets of ten genotypes of host plant multiplied in vitro were inoculated with conidial suspension of two strains of Fsd at three concentrations; $1 \times 10^{1}, 1 \times 10^{3}$, and $1 \times 10^{5}$ conidia/ml. Gnotobiotic evaluation of dual culture setup shows variations among genotypes in their response towards in vitro Fsd infection; and two genotypes (14 and 66) exhibited resistance against Fsd strains. Callus of genotypes 14 and 66 significantly restricted the fungal mycelium growth whereas callus of remaining genotypes was completely infested by Fsd mycelium within 9 days. Similarly, plantlets of genotype 14 and 66 had lesser disease severity and remained green and had fewer necrotic lesions in roots whereas plantlets of the remaining eight genotypes died within 15 days.

Conclusion: Gnotobiotic evaluation of callus and plantlets of ten genotypes of D. sissoo against Fsd strains has reduced time and space otherwise required for field trials. Genetic variations amongst the genotypes resulted in varying responses towards virulent Fsd strains and only two out of ten genotypes showed promising resistant characteristics. In dual culture setup, both callus and plantlets of the same genotypes responded similarly against Fsd strains, which signify that in vitro screening can be used as an indirect selection method for disease resistance.
\end{abstract}

Keywords: Fusarium solani f. sp. dalbergiae, Fusarium wilt, Genetic variation, Gnotobiota, In vitro screening, Shisham mortality, Plant-microbe interaction

\footnotetext{
* Correspondence: mithoojorhat@yahoo.co.in; thakura@icfre.org

${ }^{1}$ Tissue Culture Laboratory, Genetics and Tree Improvement Division, Forest

Research Institute, Dehra Dun, Uttarakhand 248006, India

Full list of author information is available at the end of the article
}

\section{Springer Open}

(c) The Author(s). 2021 Open Access This article is licensed under a Creative Commons Attribution 4.0 International License, which permits use, sharing, adaptation, distribution and reproduction in any medium or format, as long as you give appropriate credit to the original author(s) and the source, provide a link to the Creative Commons licence, and indicate if changes were made. The images or other third party material in this article are included in the article's Creative Commons licence, unless indicated otherwise in a credit line to the material. If material is not included in the article's Creative Commons licence and your intended use is not permitted by statutory regulation or exceeds the permitted use, you will need to obtain permission directly from the copyright holder. To view a copy of this licence, visit http://creativecommons.org/licenses/by/4.0/. 


\section{Background}

Dalbergia sissoo Roxb. ex DC., commonly known as shisham, is a valuable timber species in Fabaceae family, native to Afghanistan, Bangladesh, Bhutan, India, Iraq, Iran, Myanmar, Nepal, and Pakistan and introduced into Africa, Australia, China, and the USA [1-3]. It is a pioneer tree of primary succession in natural riverine forest of rivers Indus, the Ganges, Yamuna and Brahmaputra with their tributaries and also an important multipurpose tree growing outside forest which yields beautiful dark brown wood for furniture and panels, additionally used for strong poles, quality fodder, fuel wood and folk medicine [4]. The species is a suitable tree for wheatbased agroforestry system as it is deciduous and fixes nitrogen $[5,6]$.

Widespread mortality in D. sissoo (Fig. 1) has been reported from many parts of India [7-14] as well as from Bangladesh [15], Nepal [16], and Pakistan [17], and one study in India estimated a loss equivalent to US\$200 million due to mortality of 400,000 mature trees [12, 18]. Fusarium solani (Mart.) Sacc. f. sp. dalbergiae Bakshi and Singh (hereafter referred as Fsd) has been reported as one of the primary pathogenic fungi causing mortality in D. sissoo due to vascular wilt which is prevalent in the riverine plains of India, Pakistan, Nepal, and Bangladesh [8]. Other fungal pathogens viz., Fusarium oxysporum, Oxyporus latemarginatus [19], Ganoderma lucidum (Curtis) P. Karst [20], Cercospora sissoo [21],

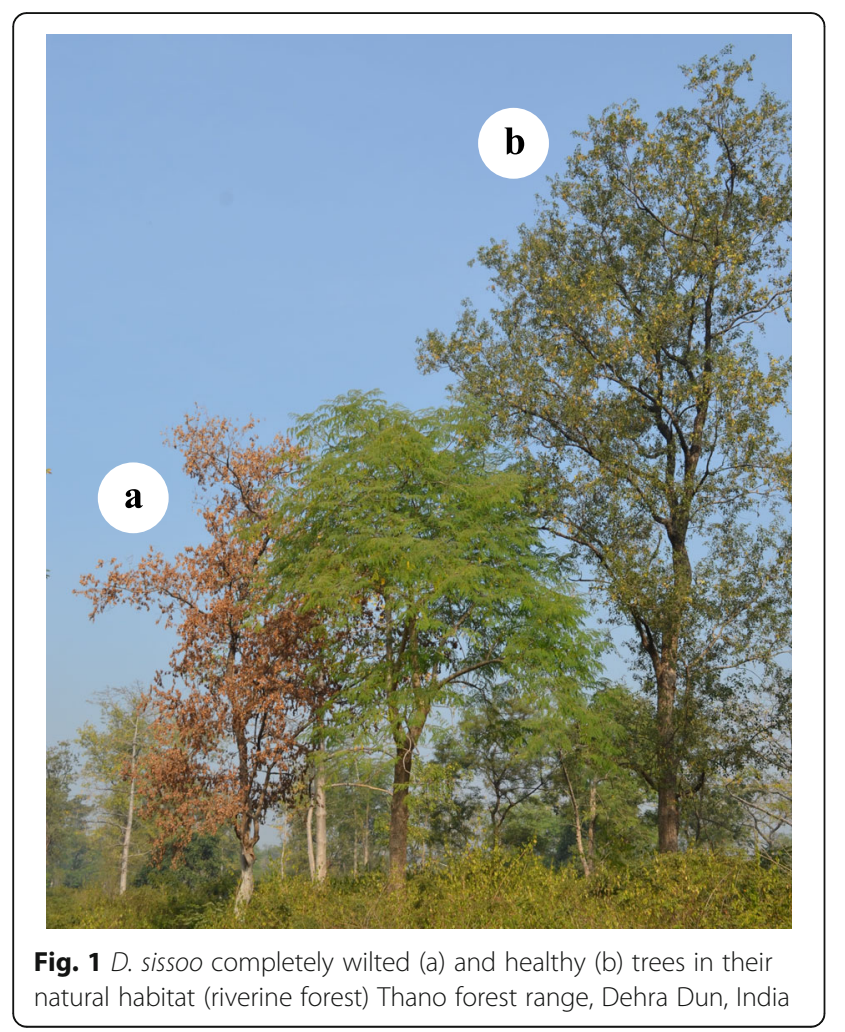

Colletogloeum sissoo, Glomerella cingulata and Septothyrella dalbergiae [22], Mycosphaerella dalbergiae [23], Phyllachora dalbergiae (=Phyllachora viventis; [24]), Phyllactinia dalbergiae [25], Maravalia achroa and Uredo sissoo [26], Ceratocystis manginecans M. Van Wyk, Al Adawi \& M. J. Wingf [27], and Lasiodiplodia theobromae (Pat.) Griffon and Maubl [28]. have also been reported for causing diseases in D. sissoo.

Tree improvement programs in developing world have largely been focused on productivity improvement of timber and to a lesser extent on disease resistance [29]. Timber tree species like $D$. sissoo have a rotation age of 30 years or more which has also added to the problem of screening for disease resistance in the field despite widely reported infections and hence, necessitates finding a quicker and reliable system to identify diseaseresistant genotypes of $D$. sissoo. Screening and selection of disease-resistant clones by in vitro co-culturing under gnotobiotic conditions of desired cloned genotypes with the fungal pathogen or toxin is an important crop improvement tool and has been adopted by different researchers [30-36]. In vitro growth condition is not only highly reproducible but also minimize the influence of external abiotic and biotic factors and ensures homogenous interaction between in vitro cultures of desirable host genotypes and inoculums of only known microbe giving a perfect gnotobiotic condition and thus, evincing a robust system to study plant-microbe interactions and facilitates estimation of resistance of desirable host plant genotypes $[37,38]$. In the present study, callus and plantlets of ten genotypes of $D$. sissoo were cocultured in vitro along with virulent strains of $F s d$ in a dual culture setup. This in vitro screening of D. sissoo genotypes against virulent strains of Fsd was aimed at studying the variability and selection of resistant $D$. sissoo genotypes which, therefore, can be used as an

Table 1 Source location of selected genotypes of D. sissoo in the study

\begin{tabular}{lllll}
\hline Sl. & Genotype & Source location & & \\
\cline { 3 - 5 } & number & Locality & District & State \\
\hline 1. & 10 & Sabalgarh, Pathri & Haridwar & Uttarakhand \\
2. & 14 & Sabalgarh, Pathri & Haridwar & Uttarakhand \\
3. & 19 & Shah Mansurpur & Saharanpur & Uttar Pradesh \\
4. & 24 & Collectorbuck Ganj & Bareilly & Uttar Pradesh \\
5. & 41 & Hasanpur, Tulsipur & Gonda & Uttar Pradesh \\
6. & 66 & Chhachhrauli Range & Yamuna Nagar & Haryana \\
7. & 201 & Hasanpur, Tulsipur & Gonda & Uttar Pradesh \\
8. & 204 & Tulsipur & Gonda & Uttar Pradesh \\
9. & 232 & Birpur-Bhambar & Gonda & Uttar Pradesh \\
10. & 237 & Bankatwa & Gonda & Uttar Pradesh \\
\hline
\end{tabular}


indirect selection method for disease-resistant genotypes of tree species [39].

\section{Methods}

\section{Plant material}

Phenotypically superior trees of D. sissoo have been selected from various parts of northern India, cloned through branch cuttings are being maintained in clonal multiplication block. Ten genotypes that were part of long-term field trials for improved productivity were selected for this study (Table 1). Genotype 14, a commercial cultivar of $D$. sissoo resistant to shisham die-back was also chosen for the study [40].

\section{Fungal material}

F. solani f. sp. dalbergiae strains (isolate no. 1145 and 1149) were procured from the National Type Culture Collection (NTCC) and were cultured in Petri dishes (9 $\mathrm{cm})$ on potato dextrose agar (PDA) medium at $25 \pm$ $2{ }^{\circ} \mathrm{C}$.

\section{In vitro establishment of aseptic cultures of $D$. sissoo Explant sterilization}

Healthy and uninfected nodal segments of the selected genotypes of D. sissoo were used for aseptic culture establishment. Explants were washed in running tap water followed by soaking in a $0.5 \%$ solution of antiseptic Cetrilak $^{\circ}$ (Cetrimide $5 \% \mathrm{w} / \mathrm{v}$, India) and then in an aqueous solution of $0.1 \%$ Bavistin $^{\circ}$ (Carbendazim WP; $50 \%$ $\mathrm{w} / \mathrm{v}$, India). Surface sterilization of explants was carried out in a laminar airflow with $0.1 \%$ Mercuric chloride $[41,42]$.

\section{Axillary bud proliferation and in vitro rooting}

Nodal segments of the branch containing single axillary bud from each accession were collected, sterilized, and inoculated. For bud induction and multiplication, bestresponded treatments, Murashige and Skoog (MS) medium [43] comprising 4.44 $\mu \mathrm{M}$ 6-Benzylaminopurine (BAP) $+2.69 \mu \mathrm{M}$ 1-Naphthaleneacetic acid (NAA) and MS medium comprising $4.44 \mu \mathrm{M}$ BAP $+1.34 \mu \mathrm{M}$ NAA, were used, respectively [41]. Cultures were maintained on standardized multiplication medium at 5 weeks interval and repeated further in subsequent sub-culturing. Micro shoots of size $>2.5 \mathrm{~cm}$ were excised and transferred for root induction in half strength MS medium supplemented with Indole-3-butyric acid (IBA) at $4.92 \mu \mathrm{M}$ concentrations [41]. Culture medium $\mathrm{pH}$ was adjusted to 5.8 and autoclaved for $15 \mathrm{~min}$ at $121^{\circ} \mathrm{C}$ and $1.0 \times 10^{5} \mathrm{~Pa}$. Incubation temperature of culture room was $25 \pm 2{ }^{\circ} \mathrm{C}$ and $55 \pm 5 \%$ relative humidity under a $16 / 8 \mathrm{hr}$ (light/dark) photoperiod with light supplied by cool-white fluorescent tubes (Philips, India) at an intensity of $35 \mu \mathrm{moles} / \mathrm{m}^{2} / \mathrm{s}$.

\section{Callus induction}

Nodal explants of D. sissoo were collected from each genotype and sterilized as mentioned earlier, further inoculated on MS medium supplemented with BAP (2.22 $6.66 \mu \mathrm{M})$ alone or in combination with 2,4-Dichlorophenoxyacetic acid $(2,4-\mathrm{D} ; 2.26-6.79 \mu \mathrm{M})$ for callus induction. The callus was maintained on MS medium supplemented with $4.44 \mu \mathrm{M}$ BAP and $2.69 \mu \mathrm{M}$ NAA in culture condition as mentioned above for further in vitro screening [41].

\section{In vitro screening and selection of resistant $D$. sissoo genotypes against Fsd Fungal inoculum preparation}

A mycelial disc (4 $\mathrm{mm}$ dia) from growing margins of the Fsd culture was transferred to an Erlenmeyer flask (250 $\mathrm{ml}$ ) containing $100 \mathrm{ml}$ Carboxy Methyl Cellulose (CMC) medium [44] for sporulation. The culture was incubated for 15 days at $25 \pm 2{ }^{\circ} \mathrm{C}$ and then viewed in a hemocytometer slide for conidial count. Consequential conidial suspension was diluted to the desired concentration $\left(1 \times 10^{1}, 1 \times 10^{3}\right.$, and $1 \times 10^{5}$ conidia/ml $)$ in the appropriate inoculation medium.

\section{Screening of callus against Fsd}

Callus of each genotype of D. sissoo was inoculated on a standardized multiplication medium. On growing callus $5 \mu \mathrm{l}$ droplet of conidial suspensions of Fsd (1145 and $1149)$ at three concentrations $\left(1 \times 10^{1}, 1 \times 10^{3}\right.$ and $1 \times$ $10^{5}$ conidia/ml) were inoculated atop the center of the callus and incubated at $25^{\circ} \mathrm{C} \pm 2$ as described before. After inoculation of callus tissue with conidial suspensions of $F s d$, the extent of infection was assessed on the 9th day by measuring the diameter of fungal growth on the tissue as well as conditions of callus, i.e., either dead or alive. Fungal growth $(\mathrm{cm})$ was measured by taking the average of diameters at both X-X' and Y-Y'axes of spread. Means of fungal radial diameter were analyzed using a parametric test.

\section{Screening of plantlets against Fsd}

In vitro rooted plantlets of each genotype of D. sissoo, were inoculated with Fsd (1145 and 1149) conidia at $1 \times$ $10^{5}$ conidia/ml concentration in $0.1 \%$ water agar supplemented with MS salts, and incubated in culture conditions as described before. The plantlets were infected only with the highest $F s d$ conidial concentration as the differences during in vitro screening of callus of ten $D$. sissoo genotypes were notably evident at this concentration. The extent of infection was assessed at regular intervals throughout a 15-day period of incubation using the following disease scores: $0=$ healthy plant, $1=$ main root tip necrotic, $2=$ whole root system infected, $3=$ stem infected and appearance of wilt symptoms, $4=$ 
whole plant wilted, and $5=$ plant dead. Infection extent of each genotype was scored from 0 to 5 at the end of 5th, 7th, 9th, 11th, 13th, and 15th days. On each observed day, means of infection extent score of genotypes were compared using non-parametric test.

\section{Experimental design and statistical analyses}

The experiments were laid in completely randomized design (CRD) with five replicates for each treatment and normal data were analyzed using analysis of variance (ANOVA) in Genstats 5 edition 3.2 for PC/Windows NT (Copyright 1995, LAWES Agricultural Trust (Rothamsted Experimental Station) and means were compared with least significant difference (LSD). Nonnormal data analyzed using Kruskal-Wallis (KW) test in SPSS statistics-23. Results with a significant difference were KW test compared using rank corresponding to mean of infection extent of plantlet of genotype on each observed day. The genotype having rank with low numerical value were resistant whereas genotype having rank with high numerical were susceptible against the inoculated isolate of $F s d$.

\section{Results}

In vitro response of callus of ten genotypes of $D$. sissoo against infection to Fsd

Results of the experiment suggest that Fsd isolates (1145 and 1149), D. sissoo genotypes, and the interaction between them had significantly affected the extent of fungal infection on the callus. High concentration $\left(1 \times 10^{5}\right.$ conidia/ml) of both isolates resulted in maximum spread of fungus $3.12 \mathrm{~cm}$ and $3.14 \mathrm{~cm}$, respectively, on callus after 9 days whereas low concentration $\left(1 \times 10^{1}\right.$ conidia/ $\mathrm{ml}$ ) of both isolates resulted in minimum spread of fungus on callus $1.04 \mathrm{~cm}$ and $1.28 \mathrm{~cm}$, respectively. Also, the extent of fungal infection on callus caused by each treatment differed significantly. Effect of $D$. sissoo genotypes on the growth of Fsd mycelium on callus was significant; fungal spread of both $F s d$ isolates 1145 and 1149 was least on callus of genotype $14(0.9 \mathrm{~cm}$ and $1.16 \mathrm{~cm}$, respectively) whereas genotypes 232 and 41 could not restrain the fungal spread of isolates 1145 and 1149, respectively, and thus, resulted in maximum spread of $2.90 \mathrm{~cm}$ and $2.89 \mathrm{~cm}$, respectively. Fungal growth on callus of genotype 66 for Fsd isolates 1145 and 1149 was $1.00 \mathrm{~cm}$ and $1.23 \mathrm{~cm}$, respectively, which is at par with genotype 14 (Table 2, Fig. 2a-d). Among the genotypes, callus of genotypes 14 and 66 showed resistance to fungal growth of both the $F s d$ isolates.

Observations on the interaction between host genotypes and conidial concentrations of Fsd isolates (1145 and 1149) revealed that maximum spread of fungus was $5.02 \mathrm{~cm}$ and $4.68 \mathrm{~cm}$, respectively, on callus of genotype 232 at $1 \times 10^{5}$ conidia/ml concentration whereas a minimum spread of fungal growth $0.77 \mathrm{~cm}$ and $1.06 \mathrm{~cm}$, respectively, was observed on callus of genotype 14 inoculated with $1 \times 10^{1}$ conidia/ml concentration. An increase in $F s d$ mycelium spread was observed in callus of genotype 232 from 1.42 to $5.02 \mathrm{~cm}$ upon increasing conidial concentration of isolate 1145 from $1 \times 10^{1}$ to $1 \times$ $10^{5}$ conidia/ml and similarly from 1.53 to $4.68 \mathrm{~cm}$ for isolate 1149 . On the other hand, genotype 14 apparently

Table 2 Effect of conidial concentration of Fsd (1145 and 1149) on callus of D. sissoo genotypes

\begin{tabular}{|c|c|c|c|c|c|c|c|c|}
\hline \multirow[t]{3}{*}{ Genotypes } & \multicolumn{8}{|l|}{ Spore concentration } \\
\hline & $1 \times 10^{1}$ & $1 \times 10^{3}$ & $1 \times 10^{5}$ & Mean $(\mathrm{cm})$ & $1 \times 10^{1}$ & $1 \times 10^{3}$ & $1 \times 10^{5}$ & Mean $(\mathrm{cm})$ \\
\hline & \multicolumn{4}{|c|}{ Fungal diameter for isolate $1145(\mathrm{~cm})$} & \multicolumn{4}{|c|}{ Fungal diameter for isolate $1149(\mathrm{~cm})$} \\
\hline 14 & 0.8 & 0.8 & 1.1 & 0.9 & 1.1 & 1.1 & 1.3 & 1.2 \\
\hline 66 & 0.9 & 0.9 & 1.3 & 1 & 1.1 & 1.1 & 1.5 & 1.2 \\
\hline 19 & 0.9 & 1.3 & 2.4 & 1.5 & 1.2 & 1.6 & 2.6 & 1.8 \\
\hline 41 & 1.0 & 1.9 & 3.0 & 2.9 & 1.2 & 2.0 & 3.0 & 2.1 \\
\hline 24 & 1.0 & 1.8 & 3.4 & 2.1 & 1.3 & 2.0 & 3.6 & 2.3 \\
\hline 10 & 1.1 & 2.2 & 3.9 & 2.4 & 1.4 & 2.3 & 3.8 & 2.5 \\
\hline 201 & 0.9 & 1.1 & 2.2 & 1.4 & 1.2 & 1.5 & 2.6 & 1.7 \\
\hline 204 & 1.2 & 2.1 & 4.2 & 2.5 & 1.4 & 2.3 & 4.0 & 2.6 \\
\hline 232 & 1.4 & 2.4 & 5.0 & 2.9 & 1.5 & 2.5 & 4.7 & 2.9 \\
\hline 237 & 1.3 & 2.3 & 4.78 & 2.8 & 1.5 & 2.4 & 4.5 & 2.8 \\
\hline \multirow[t]{5}{*}{ Mean $(\mathrm{cm})$} & 1.04 & 1.68 & 3.12 & & 1.28 & 1.88 & 3.14 & \\
\hline & Variable & \multicolumn{3}{|c|}{ LSD at $5 \%$} & \multicolumn{2}{|l|}{ Variable } & \multicolumn{2}{|l|}{ LSD at $5 \%$} \\
\hline & Genotypes & \multicolumn{3}{|l|}{0.20} & \multicolumn{2}{|c|}{ Genotypes } & \multicolumn{2}{|l|}{0.13} \\
\hline & Treatment & \multicolumn{3}{|l|}{0.29} & \multicolumn{2}{|c|}{ Treatment } & \multicolumn{2}{|l|}{0.17} \\
\hline & Genotypes $\times$ treatment & \multicolumn{3}{|l|}{0.34} & \multicolumn{2}{|c|}{ Genotypes $\times$ treatment } & 0.22 & \\
\hline
\end{tabular}



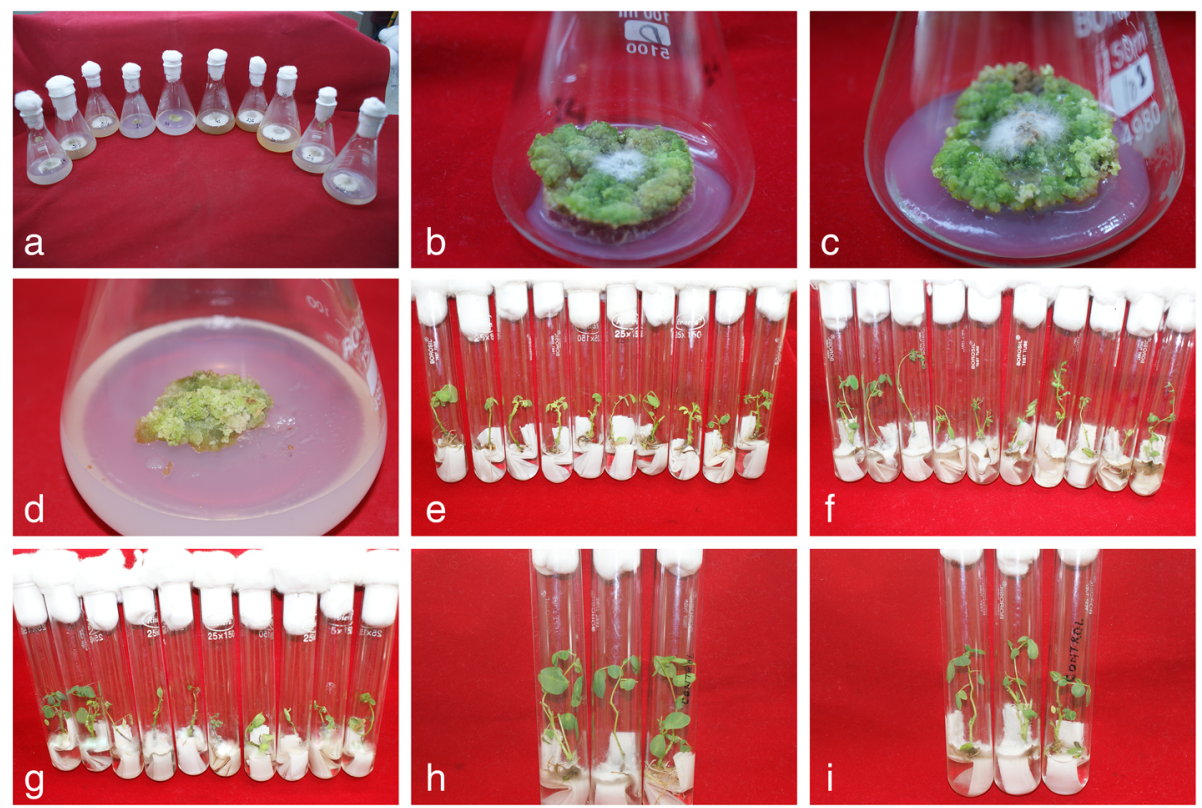

Fig. 2 a Effect of Fsd isolate 1145 on in vitro raised callus of D. sissoo genotypes, from left to right genotype 19, 237, 204, 14, 66, 41, 232, 10, 24, and 20. b Callus of genotype 14 inoculated with Fsd (1149) after 30 days of infection. c Callus of genotype 66 inoculated with Fsd (1145) after 30 days of infection. $\mathbf{d}$ Control for (a). e Control for ( $\mathbf{f}$ and $\mathbf{g}$; from left to right genotypes 14, 66, 232, 237, 204, 24, 19, 41, 201 and 10). $\mathbf{f}$ Effect of Fsd isolate 1145 on in vitro raised plantlets of ten genotypes of D. sissoo (from left to right genotypes 14, 66, 232, 237, 204, 24, 19, 41, 201 and 10). $\mathbf{g}$ Effect of Fsd isolate 1149 on in vitro raised plantlets of ten genotypes of D. sissoo (from left to right genotypes 14, 66, 232, 237, 204, 24, 19, 41, 201 and 10). h Plantlets of genotype 14 infected with both isolates of Fsd 1149 (left most test tube) and 1145 (second test tube from left) and uninfected control (third test tube from left) after 3 weeks of infection. i Plantlets of genotype 66 infected with both isolates of Fsd 1149 (left most test tube) and 1145 (second test tube from left) and uninfected control (third test tube from left) after 3 weeks of infection

restricted fungal growth of isolate 1145 on callus as no significant difference in fungal spread was observed when conidial concentration was increased from $1 \times 10^{1}$ to $1 \times$ $10^{5}$ conidia/ml. However, for isolate 1149 an increase in conidial concentration from $1 \times 10^{1}$ conidia/ml to $1 \times 10^{5}$ conidia/ml significantly affected the fungal spread on callus of genotype 14. It was interesting to note that the fungal spread on callus of genotype 14 was non-significant when concentration was increased from $1 \times 10^{1}$ to $1 \times 10^{3}$ conidia/ml as well as from $1 \times 10^{3}$ conidia/ml to $1 \times 10^{5}$ conidia/ml. Genotype 66, though not as promising as genotype 14, showed some resistance as fungal spread on callus was non-significant when conidial concentration of both isolates was increased from $1 \times 10^{1}$ to $1 \times 10^{3}$ conidia/ml, however fungal spread on callus differed significantly when conidial concentration of both isolates was increased from $1 \times 10^{3}$ conidia $/ \mathrm{ml}$ to $1 \times 10^{5}$ conidia $/ \mathrm{ml}$. In other genotypes spread on callus differed significantly when conidial concentration of both isolates was increased from $1 \times 10^{1}$ to $1 \times 10^{3}$ conidia $/ \mathrm{ml}$ as well as from $1 \times 10^{3}$ to $1 \times 10^{5}$ conidia/ml (Table 2, Fig. $2 \mathrm{a}-\mathrm{d}$ ).

\section{In vitro response of plantlets of ten genotypes of $D$. sissoo against infection of $F s d$}

Plantlets of ten genotypes of D. sissoo were screened in vitro against two isolates of $F s d$ and observation was assessed using a disease score. Disease score data was non-normal so KW test was applied and significantly varying treatments were compared using rank. Results suggest that genotype 14 ranked first on all observed days except on day seven, where it was a joint second against isolate 1149. The corresponding mean disease score of genotype 14 on day five was 0.4 against both isolates which increased to 2.4 and 2.6 against isolates 1145 and 1149, respectively, on the 15th day. Genotype 66 ranked second consistently on all observed days against both isolates and its corresponding mean disease score was 0.6 on the 5 th day which grew to 2.8 on the 15th day against both isolates. Genotype 19 managed rank 3.5 and 3.0 against 1145 and 1149 , respectively, on the 5th day, 3.0 against both isolates on the 9th day, 11th day, and 13th day but rank 6.5 on the 15th day. The corresponding mean disease score was 0.8 on day 5 th which steeply reached to 5.0 , which meant completely dead plantlets, on the 15th day, which suggests that slight resistance was shown by genotype during initial days of treatment but was lost by the 15th day. Similar results were obtained for genotype 41 .

Plantlets of susceptible genotypes were prone to infection from the beginning and maintained susceptibility throughout the observation. Genotypes 10, 24, 201, 204, 232, and 237 on the 5th day had mean disease score 
more than one and their relative ranks were $6,8.5,6.0$, 10,6 , and 8.5 , respectively, against isolates 1145 whereas against isolate 1149 their ranks were 5, 8, 8, 8, 8 and 8, respectively. Five genotypes 24, 201, 204, 232, and 237 scored more than three against isolate 1149 on 7 th day and their corresponding ranks were $8,8,8,8$, and 10 , respectively, though against isolate 1145 genotypes 10, 24, 201, 204, 232, and 237 had mean disease scores of 1.8, $2.0,1.0,1.8,1.0$, and 2.4 , respectively, and the corresponding ranks were $7.5,9,4,7.5,4$, and 10 , respectively. On the 11th day, genotypes 24, 232, and 237 had the highest mean disease scores of 5 and the corresponding ranks were 9 against isolate 1149 whereas the same genotypes had mean disease scores of 4,4 , and 4.2 , respectively, with the corresponding ranks $8.5,8.5$, and 10 , respectively, against isolates 1145 . Genotypes 10, 24, 201, 204, 232, and 237 had a mean disease score of 5 on the 13th and 15th day against both isolates (Table 3, Fig. 2e-i).

\section{Discussion}

Vascular wilt, blight, bakanae disease, etc. caused by $\mathrm{Fu}$ sarium species have been reported for widespread plant mortality [44-47]. Selection of disease-resistant plant varieties through in vitro screening has been utilized in the improvement of crops against Fusarium spp, viz. strawberry [30], Musa spp [33], wheat [48, 49], date palm [50], alfalfa plants [51], and passion fruit [52].

This study is the first report of in vitro screening and selection of resistant $D$. sissoo genotypes against Fsd vascular wilt. Among ten genotypes, it can be concluded that the callus of genotype 14 has resisted the fungal infection, followed by genotype 66 . But in genotype 66 , the resistance diminished gradually with an increase in conidial concentration to $1 \times 10^{5} \mathrm{conidial} / \mathrm{ml}$. Similar studies of callus-fungal interactions for disease resistance selection have been reported in woody species like Acacia pulchella, Eucalyptus calophylla, E. marginata [31], Pinus eschinata and P. virginiana [53], Prunus persica [54], Pinus ellottii [55], Citrus sinensis and C. limon [56], Fagus sylvatica [57], Pinus nigra and P. sylvestris [58], and Malus domestica [59].

In vitro cloned plantlets of $D$. sissoo genotypes infected under in vitro condition with conidial suspension of Fsd showed results similar to callus. After infection, it was observed that fungal mycelium grew rapidly and a cottony mass of mycelium could be seen around the rhizosphere of plantlets, which may be due to humid conditions of the culture vessels providing a favorable environment for mycelial growth [60]. Nonetheless, on the 15th day of observation, plantlets of genotypes 14 and 66 had a significantly lesser disease severity index (between 2 to 3 ) implying that initial symptoms of wilt appeared after fungal growth around the rhizosphere but the plantlets remained green, healthy, and had fewer necrotic lesions in the roots whereas plantlets of remaining eight genotypes completely wilted and died. Similar findings have been reported for other plantletmicrobe interactions $[33,51,53,61-65]$.

In vitro screening of clonal host genotypes against specific strains of the pathogen in a dual culture setup is a perfect system for gnotobiotic studies in plant-microbe interaction and it gives an opportunity to estimate the resistance or susceptibility of clones of host plant (D. sissoo genotypes) by ensuring only one microbe ( $F s d$ isolate in this case) is infecting only one host genotype in a culture flask in axenic condition with growth environment. Plantlets with complete root and shoot system or callus (mostly representing the unorganized cellular growth) both of the same genotype showed a similar trend. Growth condition and nutrient rich MS growing media favor the growth of microbe rather than the host in this dual culture setup and thus ensuring strict criteria for selection of resistant genotypes.

\section{Conclusions}

The study, thus, concludes, that callus of two genotypes of D. sissoo (14 and 66) showed resistance against Fsd under in vitro conditions whereas the remaining eight genotypes were susceptible. Similar results were observed for in vitro screening of plantlets of $D$. sissoo genotypes against $F s d$. This suggests that in vitro screening of candidate genotypes of $D$. sissoo against Fsd under gnotobiotic conditions may be an effective as well as a quick method for screening and selection of diseaseresistant genotypes. Moreover, by this method, a large number of $D$. sissoo genotypes could be screened in limited time and space, hence, assisting in the process of screening and selection of disease-resistant genotypes.

\section{Abbreviations}

PDA: Potato dextrose agar; MS: Murashige and Skoog basal media; BAP: 6Benzylaminopurine; NAA: 1-Naphthaleneacetic acid; IBA: Indole-3-butyric acid; 2,4-D: 2,4-Dichlorophenoxyacetic acid; CMC: Carboxymethyl cellulose; Fsd: Fusarium solani f. sp. dalbergiae; CRD: Completely randomized design; ANOVA: Analysis of variance; LSD: Least significant difference; KW: KruskalWallis test

\section{Acknowledgements \\ Authors acknowledge Dr. Ashok Kumar, Genetics and Tree Improvement Division, FRI, Dehra Dun for providing D. sissoo genotypes and Head, Forest Protection Division, Forest National Type Culture Collection, FRI, Dehra Dun India, for providing the fungal strains. The authors thank the Director and Vice Chancellor, FRI Deemed University, Dehra Dun, India, for providing facilities to conduct the study.}

\section{Authors' contributions}

MC and AT conceived and designed the research on in vitro studies. NSKH helped in fungal studies. MC performed the experiments. AT, MC and YS analyzed the results. MC, YS and MMR wrote the manuscript with assistance from AT and NSKH. All authors have read and agreed to the published version of the manuscript. 


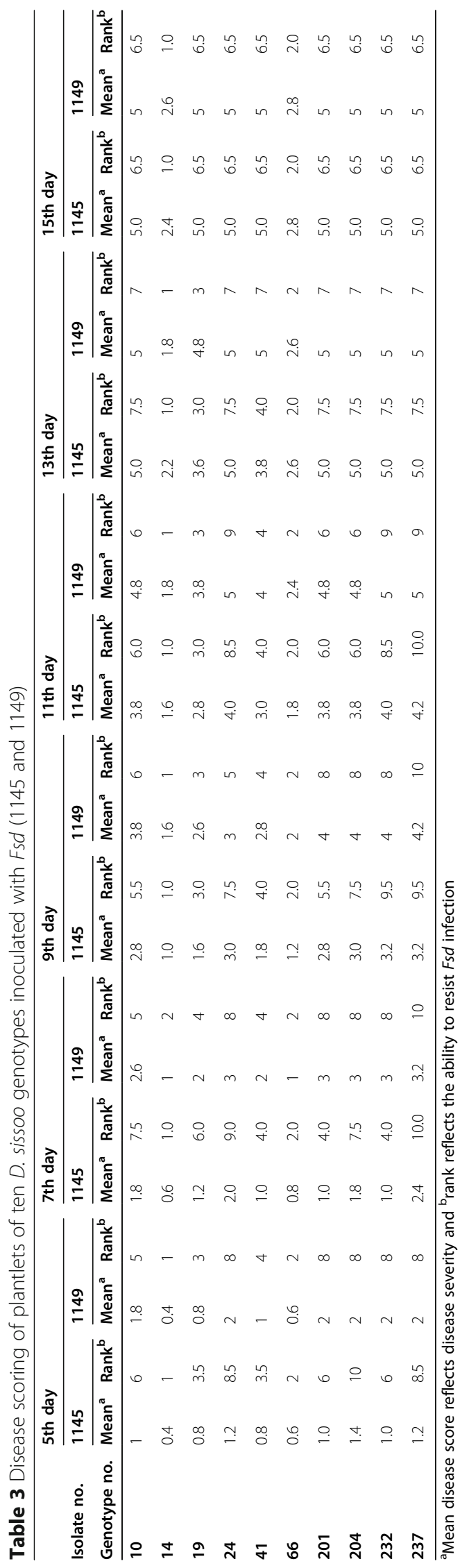




\section{Funding}

This research received no external funding.

\section{Availability of data and materials}

Not applicable.

\section{Ethics approval and consent to participate}

Not applicable.

\section{Consent for publication}

Not applicable.

\section{Competing interests}

The authors declare that they have no competing interests.

\section{Author details}

${ }^{1}$ Tissue Culture Laboratory, Genetics and Tree Improvement Division, Forest Research Institute, Dehra Dun, Uttarakhand 248006, India. ${ }^{2}$ Faculty of Forestry, SKUAST-Kashmir, Benehama, Ganderbal, Jammu and Kashmir, India. ${ }^{3}$ Forest Pathology Division, Forest Research Institute, Dehra Dun, Uttarakhand 248006, India.

\section{Received: 24 September 2020 Accepted: 3 February 2021}

Published online: 23 February 2021

\section{References}

1. Thothathri K (1987) Taxonomic revision of the tribe Dalbergieae in the Indian subcontinent. Botanical Survey of India, Kolkata

2. International Legume database and Information service (2018) https://ildis. org/cgi-bin/Araneus.pl?version 10.01\&LegumeWeb\&tno 1149\&genus Da Ibergia\&species sissoo. Accessed 15 Apr 2020

3. Singh Y, Thakur A, Varshney VK, Harsh NSK, Chauhan M (2018) Qualitative ergosterol determination can confirm fungal infection in shisham. Indian For 144:1224-1225

4. Tewari DN (1994) A monograph on Dalbergia sissoo Roxb. International Book Distributors, Dehra Dun

5. Subhan F (1990) Financial analysis of selected shelterbelts system in Pakistan. Pak J For 40:247-252

6. Luna RK (1996) Plantation trees. International Book Distributors, Delhi

7. Bagchee KD (1945) Wilt and dieback of shisham, babul, and khair in the artificial regeneration under agriculture-cum forestry management. Indian For 71:20-24

8. Bakshi BK (1954) Wilt of shisham (Dalbergia sissoo Roxb.) due to Fusarium solani sensu Snyder and Hansen. Nature 174:278-291. https://doi.org/10.103 $8 / 174278 \mathrm{a} 0$

9. Shukla AN (2002) Mortality of Dalbergia sissoo in India. Indian For 128:12091215

10. Dayaram MK, Sharma S, Chaturvedi PP (2003) Shisham mortality in Bihar: extent and causes. Indian Phytopathol 56:384-387

11. Dogra AS, Nautiyal S, Nautiyal DP, Singh G (2006) Field performance of twenty three clones of Dalbergia sissoo in clonal seed orchard. Indian For 132:273-280

12. Shukla AN (2008) Resistance of Dalbergia sissoo to Fusarium solani f. sp. dalbergiae. For Pathol 38:410-418. https://doi.org/10.1111/j.1439-0329.2008. 00563.x

13. Shukla AN, Harsh NSK (2010) Extent and evaluation of die back disease of shisham (Dalbergia sissoo) and identification of disease resistance sources; project completion report. Indian Council of Forestry Research and Education, Dehra Dun

14. Patel AK, Dayaram (2017) Effect of biotic and abiotic stresses on shisham (Dalbergia sissoo Roxb.) mortality in Bihar. Environ Ecol 35:1218-1222

15. Webb EL, Hossain SMY (2005) Dalbergia sissoo mortality in Bangladesh plantations: correlations with environmental and management parameters. Forest Ecol Manag 206:61-69. https://doi.org/10.1016/j.foreco.2004.10.055

16. Shakya DD, Lakhey PB (2007) Confirmation of Fusarium solani as the causal agent of die-back of Dalbergia sissoo in Nepal. Plant Pathol 56:1041-1041. https://doi.org/10.1111/j.1365-3059.2007.01637.x

17. Mukhtar I, Bajwa R, Nasim G (2015) Major constraints on shisham (Dalbergia sissoo) plantations and pathological debate on dieback disease in Punjab, Pakistan. J For Res 26:267-271. https://doi.org/10.1007/s11676-015-0081-5
18. Shukla AN (2003) Mortality in plantations of Dalbergia sissoo raised from seedlings and clonal material. Indian For 129:1493-1498

19. Centre for Agriculture and Bioscience International (2008) Invasive species compendium. https://www.cabi.org/isc/datasheet/17808. Accessed 8 Jan 2020

20. Harsh NSK, Chandra S, Uniyal K (2011) Screening resistance of Dalbergia sissoo clones against Ganoderma lucidum root rot disease in field conditions. For Pathol 41:221-226. https://doi.org/10.1111/j.1439-0329.2010. 00685.x

21. Sydow H, Mitter JH (1933) Fungi indici I. Annlo Mycol 31:84-97

22. Pavgi MS, Singh RA (1971) Parasitic fungi from North India. Sydowia 24:113119

23. Browne FG (1968) Pests and diseases of forest plantation trees: an annotated list of the principal species occurring in the British Commonwealth. Clarendon Press, Oxford University Press, Oxford

24. Saccardo PA (1883) Phyllachora dalbergiae. Sylloge fungorum omnium hucusque cognitorum Vol II, p 594

25. Pirozynski KA (1965) Ovulariopsis state of Pleochaeta. Mycologia 57:826-828

26. Bakshi BK, Singh S (1967) Rusts on Indian forest trees. Indian Forest Rec (N.S. ) For Pathol 2:139-198

27. Al Adawi AO, Barnes I, Khan IA, Al Subhi AM, Al Jahwari AA, Deadman ML, Wingfield BD, Wingfield MJ (2013) Ceratocystis manginecans associated with a serious wilt disease of two native legume trees in Oman and Pakistan. Australas Plant Path 42:179-193. https://doi.org/10.1007/s13313-012-0196-5

28. Chandra S, Prasad R, Harsh NSK, Ahuja R, Khatri S (2014) Bark canker and die-back of Dalbergia sissoo in Haryana and Punjab caused by Lasiodiplodia theobromae. Indian For 140:76-79

29. Kumar A, Rathore TS, Palanisamy K, Viswanath S (2016) Advances in tree improvement and forest genetic resources conservation and management. Greenfields publishers, Dehra Dun

30. Toyoda H, Horikoshi K, Yamano Y, Ouchi S (1991) Selection for Fusarium wilt disease resistance from regenerants derived from leaf callus of strawberry. Plant Cell Rep 10:167-170. https://doi.org/10.1007/BF00234287

31. McComb JA, Hinch JM, Clarke AE (1987) Expression of field resistance in callus tissue inoculated with Phytophthora cinnamomi. Phytopathology 77 346-351. https://doi.org/10.1094/Phyto-77-346

32. Predieri S (2001) Mutation induction and tissue culture in improving fruits Plant Cell Tiss Org 64:185-210. https://doi.org/10.1023/A:1010623203554

33. Wu YL, Yi GJ, Peng XX (2010) Rapid screening of Musa species for resistance to Fusarium wilt in an in vitro bioassay. Eur J Plant Pathol 12:409-415. https://doi.org/10.1007/s10658-010-9669-y

34. Maksimov I, Troshina N, Surina O, Cherepanova E (2014) Salicylic acid increases the defense reaction against bunt and smut pathogens in wheat calli. J Plant Interact 9:306-314. https://doi.org/10.1080/17429145.2013.832424

35. Singh Y, Thakur A, Varshney VK, Harsh NSK (2019) Ergosterol quantification: a tool to measure fungal infection in plant tissue. Res J Biotechnol 14:86-88

36. Fenning TM (2019) The use of tissue culture and in-vitro approaches for the study of tree diseases. Plant Cell Tiss Org 136:415-430. https://doi.org/10.1 007/s11240-018-01531-0

37. Miebach M, Schlechter RO, Clemens J, Jameson PE, Remus-Emsermann MNP (2020) Litterbox-A gnotobiotic zeolite-clay system to investigate Arabidopsis-microbe interactions. Microoraganisms 8:464. https://doi.org/ 0.3390/microorganisms8040464

38. Nawrot-Chorabik K (2013) The use of dual cultures in vitro to evaluate the pathogenicity of fungi and host genotype susceptibility in immunological studies of woody plants. In: Petre M (ed) Environmental biotechnology new approaches and prospective applications. InTech open science Publisher, London, p 287-301. https://doi.org/10.5772/53214

39. Ostry ME, Skilling DD (1992) Application of tissue culture for studying tree defense mechanisms. In: Blanchette RA, Biggs AR (eds) Defense mechanisms of woody plants against fungi. Springer, Berlin, pp 405-423

40. Press Information Bureau (2011). Ministry of Environment, Forests and Climate Change, Government of India. http://shek.nic.in/newsite/PrintRelea se.aspx?relid=76022. Accessed 10 June 2018.

41. Panwar M (2014) In vitro studies on Dalbergia sissoo against Fusarium solani wilt. Doctoral Dissertation, Forest Research Institute (Deemed to be) University, Dehra Dun

42. Kunwar A, Thakur A, Rather MM (2018) In vitro plant regeneration from cotyledonary node of Diploknema butyracea. Res J Biotechnol 13:29-36 
43. Murashige T, Skoog F (1962) A revised medium for rapid growth and bio assays with tobacco tissue culture. Physiol Plant 15:473-497. https://doi. org/10.1111/j.1399-3054.1962.tb08052.x

44. Booth C (1971) The genus Fusarium. Commonwealth Mycological Institute, Kew, Surrey

45. Nicolli CP, Spolti P, Tibola CS, Fernandes JMC, Del Ponte EM (2015) Fusarium head blight and trichothecene production in wheat by Fusairum graminearum and F. meridionale applied alone or in mixture at post-flowering. Trop Plant Pathol 40:134-140. https://doi.org/10.1007/s40858-015-0017-9

46. Yerkovich N, Palazzini JM, Sulyok M, Chulze SN (2017) Trichothecene genotypes, chemotypes and zearalenone production by Fusarium graminearum species complex strains causing Fusarium head blight in Argentina during an epidemic and non-epidemic season. Trop Plant Pathol 42:190-196. https://doi.org/10.1007/s40858-017-0155-3

47. Singha IM, Kakoty Y, Unni BP, Das J, Kalita MC (2016) Identification and characterization of Fusarium sp. using ITS and RAPD causing Fusarium wilt of tomato isolated from Assam, North East India. J Genet Eng Biotechnol 14: 99-105. https://doi.org/10.1016/j.jgeb.2016.07.001

48. Ahmed KZ, Mesterházy Á, Bartók T, Sági F (1996) In vitro techniques for selecting wheat (Triticum aestivum L.) for Fusarium-resistance. II. Culture filtrate technique and inheritance of Fusarium-resistance in the somaclones. Euphytica 91:341-349. https://doi.org/10.1007/BF00033096

49. Browne RA, Cooke BM (2005) Resistance of wheat to Fusarium spp. in an in vitro seed germination assay and preliminary investigations into the relationship with Fusarium head blight resistance. Euphytica 141:23-32. https://doi.org/10.1007/s10681-005-4820-0

50. El Hadrami A, El Idrissi-Turan A, El Hassni M, Daayf F, El Hadrami I (2005) Toxin-based in-vitro selection and its potential application to date palm for resistance to the bayoud Fusarium wilt. CR Biol 328:732-744. https://doi. org/10.1016/j.crvi.2005.05.007

51. Arcioni S, Pezzotti M, Damiani F (1987) In vitro selection of alfalfa plants resistant to Fusarium oxysporum f. sp. medicaginis. Theor Appl Genet 74: 700-705. https://doi.org/10.1007/BF00247544

52. Flores PS, Otoni WS, Dhingra OS, Souza Diniz SPS, Santos TM, Bruckner CH (2012) In vitro selection of yellow passion fruit genotypes for resistance to Fusarium vascular wilt. Plant Cell Tiss Org 108:37-45. https://doi.org/10.1007/ s11240-011-0009-5

53. Jang JC, Tainter FH (1990) Cellular responses of pine callus to infection by Phytophthora cinnamomi. Phytopathology 80:1347-1352. https://doi.org/10.1 094/Phyto-80-1347

54. Hammerschlag FA (1990) Resistance responses of plant regenerated from Peach callus, cultures to Xanthomonas campestris pv. pruni. J AM Soc Hortic Sci 115:1034-1037. https://doi.org/10.21273/JASHS.115.6.1034

55. Bronson MR, Li Y, Dixon RK, Runion GB, Kelley WD, Peterson CM (1992) In vitro host-pathogen interactions of Pinus elliottii calli and Fusarium moniliforme var. subglutinans. Eur J Forest Pathol 22:432-440. https://doi. org/10.1111/j.1439-0329.1992.tb00317.x

56. Gentile A, Tribulato E, Continella G, Vardi A (1992) Differential responses of citrus calli and protoplasts to culture filtrate and toxin of Phoma tracheiphila. Theor Appl Genet 83:759-764. https://doi.org/10.1007/BF00226695

57. Hendry SJ, Boddy L, Lonsdale D (1993) Interaction between callus cultures of European beech, indigenous ascomycetes and derived fungal extracts. New Phytol 123:421-428. https://doi.org/10.1111/j.1469-8137.1993.tb03753.x

58. Ragazzi A, Moricca S, Dellavalle I (1995) Growth of axenic cultures of Cronartium flaccidum on callus tissue from Pinus nigra var. laricio and Pinus sylvestris. Eur J Forest Pathol 25:31-37. https://doi.org/10.1111/j.1439-0329.1 995.tb01069.x

59. Raman H, Goodwin PB (2008) In vitro screening of apple germplasm for resistance against black spot caused by Venturia inaequalis. J New Seeds 2 : 37-46. https://doi.org/10.1300/J153v02n02_03

60. Gretenkort MA, Ingram DS (1993) The use of ergosterol as a quantitative measure of the resistance of cultured tissues of Brassica napus ssp. oleifera to Leptosphaeria maculans. J Phytopathol 138:217-224. https://doi.org/1 0.1111/j.1439-0434.1993.tb01379.x

61. Diner AM, Mott RL (1985) In vitro inoculation of western white pine tissue culture propagules with vegetative hyphae of Cronartium ribicola. Phytopathology 75:1130-1131. https://doi.org/10.1094/Phyto-75-1130

62. Gretenkort MA, Helsper JPG (1993) Disease assessment of pea lines with resistance to foot rot pathogens: protocols for in vitro selection. Plant Pathol 42:676-685. https://doi.org/10.1111/j.1365-3059.1993.tb01552.x
63. Sowik I, Bielenin A, Michalczuk L (2001) In vitro testing of strawberry resistance to Verticillium dahaliae and Phytophthora cactorum. Sci Hortic 88: 31-40. https://doi.org/10.1016/S0304-4238(00)00195-3

64. Singh N, Somai BM, Pillay D (2005) In vitro screening of sugarcane to evaluate smut susceptibility. Plant Cell Tiss Org 80:59-266. https://doi.org/1 0.1007/s11240-004-1017-5

65. Mora RE, Rodriguez MA, Gayosso LY, López CE (2019) Using in vitro plants to study the cassava response to Xanthomonas phaseoli pv. manihotis infection. Trop Plant Pathol 44:423-429. https://doi.org/10.1007/s40858-01900296-x

\section{Publisher's Note}

Springer Nature remains neutral with regard to jurisdictional claims in published maps and institutional affiliations.

\section{Submit your manuscript to a SpringerOpen ${ }^{\circ}$ journal and benefit from:}

- Convenient online submission

- Rigorous peer review

- Open access: articles freely available online

High visibility within the field

- Retaining the copyright to your article

Submit your next manuscript at $\boldsymbol{\nabla}$ springeropen.com 